\title{
'Erythropoietic' protoporphyria and cirrhosis in sisters
}

\author{
R. P. H. THOMPSON ${ }^{1}$, E. A. MOLLAND, D. C. NICHOLSON, \\ AND C. H. GRAY \\ From the Department of Chemical Pathology, King's College Hospital, London, and the \\ Department of Morbid Anatomy, London Hospital, London
}

SUMmARY The clinical and histopathological features of two sisters with erythropoietic protoporphyria and liver disease are described. They had unusually severe photosensitivity with blistering, and both died at the age of 31 from cirrhosis. The association of erythropoietic protoporphyria with several hepatic abnormalities is discussed.

Erythropoietic protoporphyria was first differentiated from other solar urticarias by Magnus, Jarrett, Prankerd, and Rimington (1961). Exposure to the sun produces burning erythema and thickening of the skin of affected patients, but blistering is rare. Plasma, red cells, and faeces contain a large excess of protoporphyrin, and the faecal excretion of coproporphyrin is increased to a lesser extent. The condition is inherited as an autosomal dominant characteristic. In 1968, Barnes, Hurworth, and Millar described a patient with the condition who died at the age of 42 , after a history of only three months, with deep jaundice, hepatic failure and cirrhosis. Four other patients with erythropoietic protoporphyria and cirrhosis have recently been reported (Donaldson, McCall, Magnus, Simpson, Caldwell, and Hargreaves, 1971; Schmidt and Stich, 1971; Scott, Ansford, Webster, and Stringer, 1973). We describe two sisters with erythropoietic protoporphyria who had life-long photosensitivity, followed later by severe blistering, and who both became jaundiced and died at the age of 31 with cirrhosis.

\section{Patient Reports}

The two patients were sisters. There was no history of photosensitivity in their other nine siblings or in the parents.

\section{PATIENT 1}

Since the age of 5 she had had severe photosensitivity of the skin, and stayed indoors in summer. There

${ }^{1}$ Reprint requests to R.H.P.T., St Thomas' Hospital London, SE1, UK.

Received for publication 15 August 1973. was burning, erythema, swelling, and ulceration, but little scarring. She first became jaundiced in 1950 at the age of 19 (maximum serum bilirubin $25 \mathrm{mg}$ per $100 \mathrm{ml}$; alkaline phosphatase $13 \mathrm{King}$-Armstrong units per $100 \mathrm{ml}$ ) and this lasted for four months. Haemorrhagic blisters then occurred after exposure to sun while she was jaundiced. A year later jaundice recurred (maximum bilirubin 19.6; alkaline phosphatase 18) and lasted two months; painful haemorrhagic bullae again developed after exposure to sunlight (fig 1). A small area of skin was exposed to sunlight for four minutes when the serum bilirubin was $8 \mathrm{mg}$ per $100 \mathrm{ml}$ and this produced pain and oedema. Two months later, when the bilirubin was $2.2 \mathrm{mg}$ per $100 \mathrm{ml}$, a similar exposure produced only slight erythema.

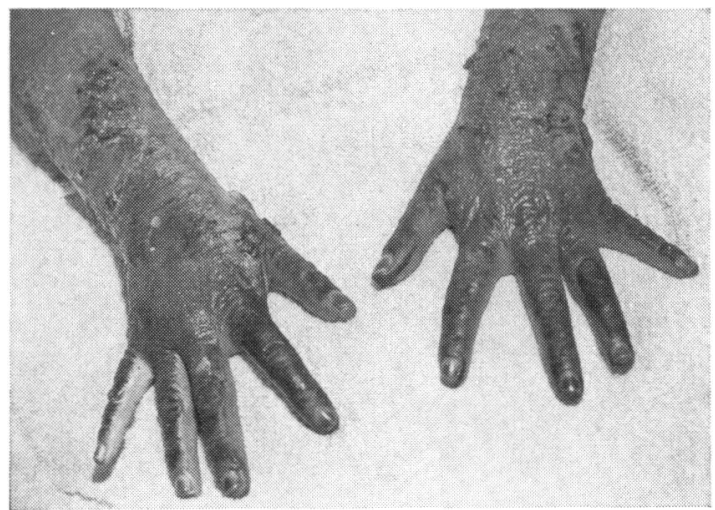

Fig 1 Haemorrhagic blisters of skin of patient 1 when she was jaundiced. 


\begin{tabular}{|c|c|c|c|c|c|c|}
\hline \multirow[t]{2}{*}{ Age } & & \multicolumn{2}{|l|}{ Faeces } & \multirow{2}{*}{$\begin{array}{l}\text { Urine } \\
\text { Coproporphyrin } \\
\text { ( } \mu \mathrm{g} \text { per } 24 \mathrm{hr})\end{array}$} & \multicolumn{2}{|l|}{ Red Cells } \\
\hline & & $\begin{array}{l}\text { Coproporphyrin } \\
\text { ( } \mu \mathrm{g} \text { per } 24 \text { hrs) }\end{array}$ & Protoporphyrin & & $\begin{array}{l}\text { Coproporphyrin } \\
\text { ( } \mu \mathrm{g} \text { per } 100 \mathrm{ml} \text { packed }\end{array}$ & $\begin{array}{l}\text { Protoporphyrin } \\
\text { cells) }\end{array}$ \\
\hline Patient 1 & $\begin{array}{l}22 \\
23\end{array}$ & $\begin{array}{l}1453 \\
(200-2890) \\
2710 \\
(1920-3740)\end{array}$ & $\begin{array}{l}2430 \\
(330-6170) \\
8620 \\
(5740-13000)\end{array}$ & $\begin{array}{l}492 \\
(170-1230) \\
\text { N.E. }\end{array}$ & N.E. & N.E. \\
\hline
\end{tabular}

Table Mean and range of faecal, urinary, and red-cell copro- and protoporphyrin levels 1

${ }^{1}$ Normal values from Rimington (1961) (urine and red cell) and England, Cotton, and French (1962) (faeces). N.E. $=$ not estimated.

At the age of 22 a further attack of jaundice occurred (maximum bilirubin 18.6; alkaline phosphatase 23 units) but without bullae. The liver was noticed to be enlarged, and a needle biopsy of the liver was performed when the serum bilirubin was $4.1 \mathrm{mg}$ per $100 \mathrm{ml}$. She was free of jaundice for six years but it then recurred and lasted for three months (maximum bilirubin 6.4 ; alkaline phosphatase 15), again without bullae. At 30 she had a normal delivery of a healthy child, but was readmitted two months later with jaundice and blistering. She slowly deteriorated with low serum levels of prothrombin and albumin, the serum bilirubin rose to $19 \mathrm{mg}$ per $100 \mathrm{ml}$, and the alkaline phosphatase to $26 \mathrm{KA}$ units, and after several haematemeses she died in hepatic failure at the age of 31.

Faecal and urine porphyrins were measured during the first years of her illness (see table). Levels of faecal copro- and protoporphyrins were greatly raised, and urinary coproporphyrin was intermittently raised. Protoporphyrin was detected spectroscopically in excess in the plasma, but red cell protoporphyrin was not determined. The greatest urinary coproporphyrin level occurred with the jaundice, but faecal porphyrin levels were not well correlated with serum bilirubin values.

Studies with ${ }^{15} \mathrm{~N}$-glycine at the age of 19 showed a normal red cell survival, but the utilization of glycine for the synthesis of early labelled urobilin was twice normal (Nicholson, Cowger, Kalivas, Thompson, and Gray, 1973).

\section{PATIENT 2}

The younger sister of patient 1 was well until 1961, when at the age of 29 she first became jaundiced (serum bilirubin $6.0 \mathrm{mg}$ per $100 \mathrm{ml}$ ). A straight abdominal radiograph showed a calcified gallstone. The bilirubin level remained abnormal during the next two years, hepatosplenomegaly developed, and she, like her sister, died at the age of 31 , deeply jaundiced with hepatic failure.

Faecal and urinary porphyrins were measured during her last year of life and showed greatly raised levels of copro- and protoporphyrins in the faeces, and intermittently raised levels of coproporphyrin in the urine (see table). The red cells contained a large excess of protoporphyrin.

Studies with ${ }^{15} \mathrm{~N}$-glycine also showed a high utilization of glycine for the synthesis of early labelled urobilin (Nicholson et al, 1973).

\section{Histopathology}

\section{PATIENT 1}

Histological examination of the liver biopsy specimen taken at the age of 22 showed that the lobular structure was well preserved, but portal tracts were widened, and there was septa formation (fig 2). In some areas the liver cell plates had an alveolar pattern, suggesting regeneration, but there were no mitoses and no individual cell necroses. Granules of dark-brown pigment were present within liver cells, as plugs in canaliculi, in Kupffer cells, and in macrophages in the portal tracts (figs 2 and 3 ). There was moderate lymphocyte infiltration of portal tracts.

At postmortem examination there was coarse cirrhosis of the liver, which weighed $1850 \mathrm{~g}$ and was deeply bile-stained. The gallbladder was normal, and there were no gallstones. Microscopical examination of the liver showed a mixed cirrhosis, with much bile-duct proliferation, and a moderate lymphocyte infiltration of the septa. The hepatocytes showed degenerative changes, partly due to postmortem autolysis. There was moderate fatty infiltration. Dark brown pigment was present throughout the nodules, again forming granules within hepatocytes and Kupffer cells, dense plugs in canaliculi, and occasionally plugs in bile ducts within the septa. The pigment in the biopsy and postmortem liver specimens was negative with long ZiehlNielsen stain and weakly positive with Sudan Black. The Prussian blue reaction for iron was negative.

Formalin-fixed glycerol-mounted sections were 


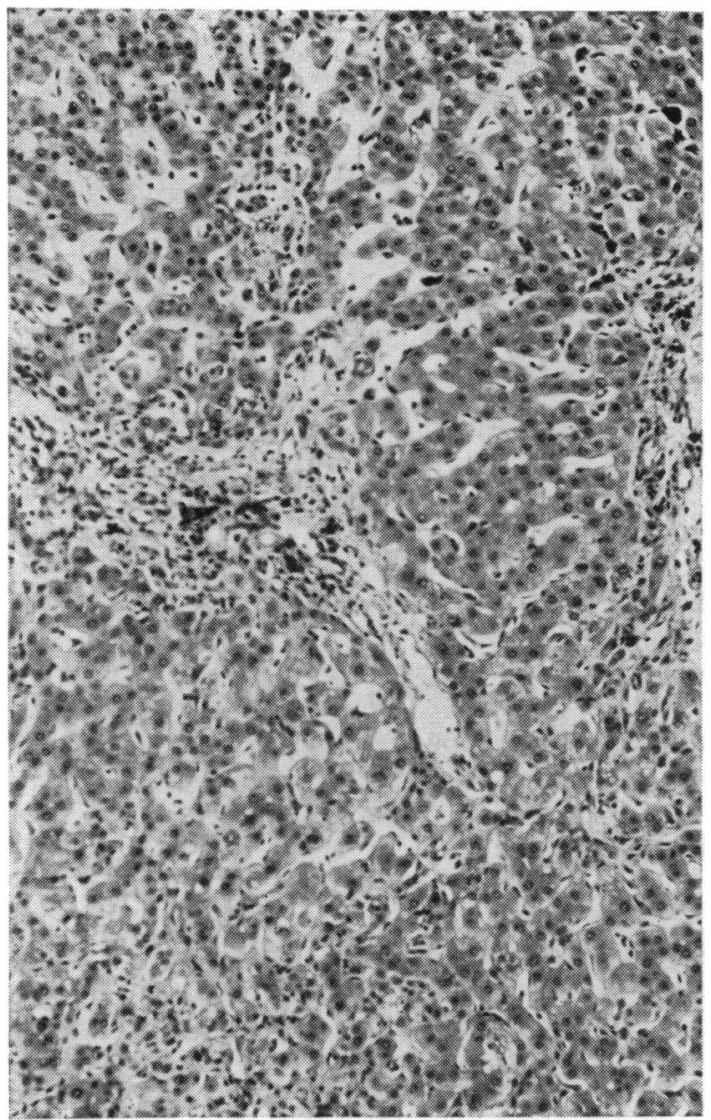

Fig 2 Liver biopsy specimen from patient 1, showing widening of portal tracts and septa. Haematoxylin and $\operatorname{eosin} \times 30$.

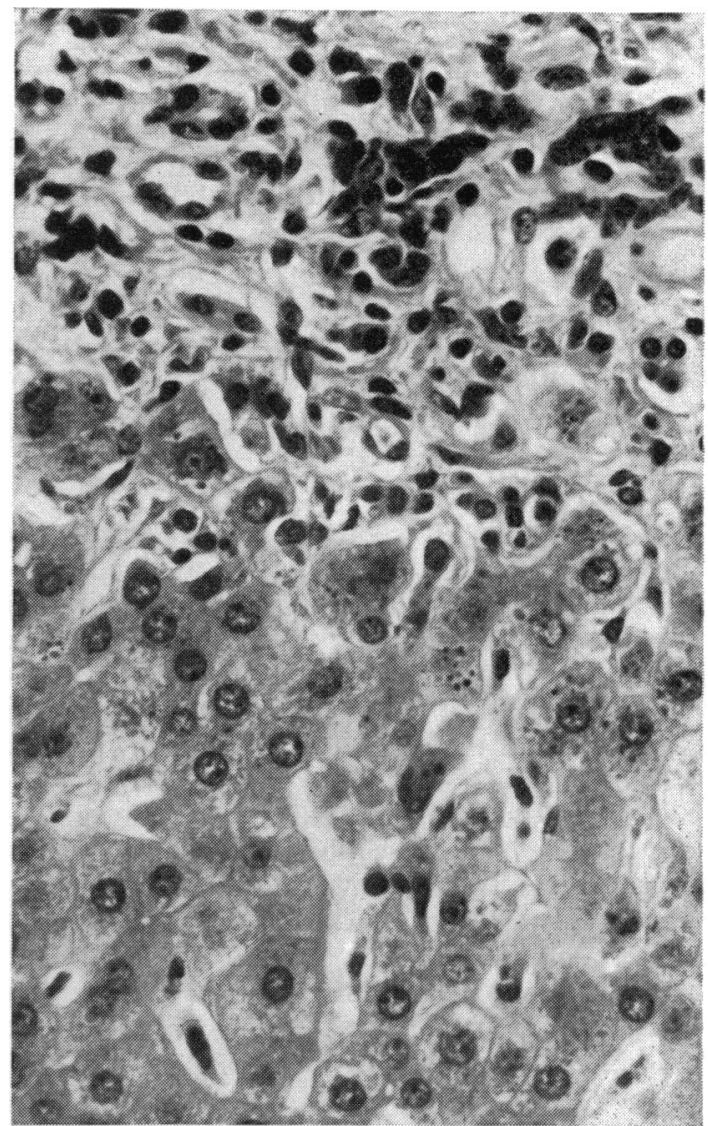

Fig 3 High-power view of fig 2, showing pigment granules in hepatocytes, Kupffer cells, and macrophages. $\times 120$.

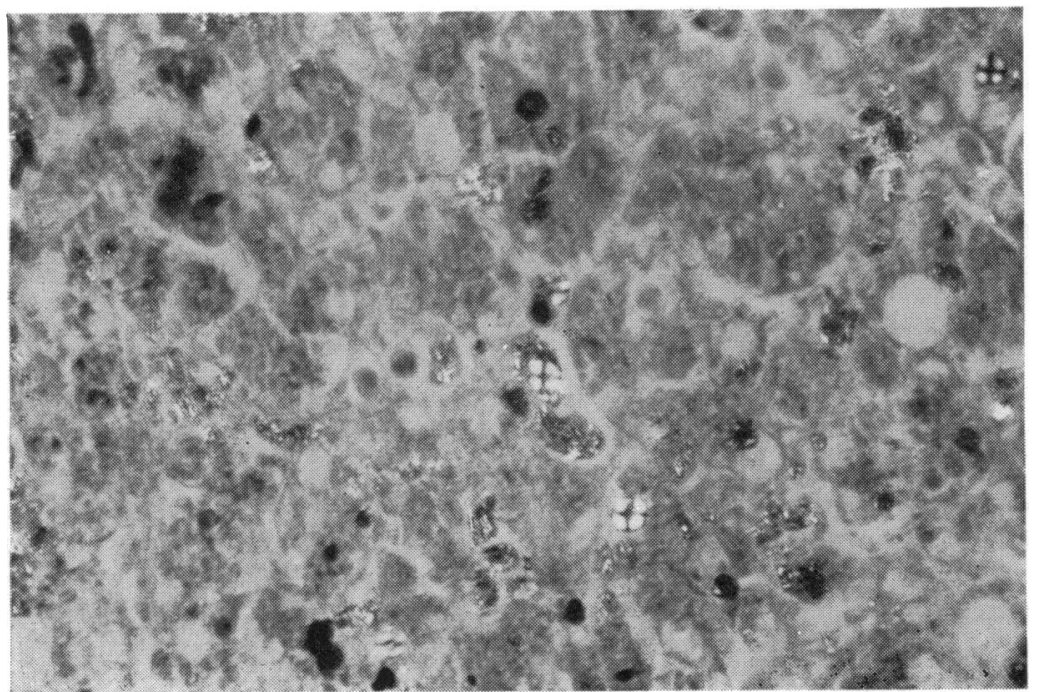

Fig 4 Postmortem liver specimen from patient 1 , showing Maltese crosses and birefringent crystals. Polarizing light $\times 30$. 
examined under ultraviolet light using a mercury vapour arc source and a Schott B.G. 12 primary filter. The brown pigment gave red autofluorescence. Under polarized light the pigment was birefringent, and was weakly positively birefringent using a quartz sensitive tint plate. Maltese cross figures were seen in some of the hepatocyte granules and in canalicular plugs, especially in the postmortem material (fig 4), but not in the pigment in Kupffer cells. However, where the pigment gave a Maltese cross it did not autofluoresce under ultraviolet light.

There was some cholestasis. Fouchet's stain demonstrated dark green bile, whereas protoporphyrin pigment remained dark red-brown and could therefore be distinguished from bile plugs within canaliculi. Bile was negative under polarized and ultraviolet light.

Enlarged lymph nodes from the porta hepatis also contained the brown pigment but there was none in the other tissues examined.

\section{PATIENT 2}

Microscopical examination of the liver at necropsy showed a cirrhosis, similar to that of patient 1 , with bile duct proliferation, and a lymphocyte infiltration of the septa. Dark-brown pigment was present, although less extensively than in patient 1 , and it had a similar distribution in granules within liver cells, in Kupffer cells, as plugs in canaliculi and in the septa. The characteristic red autofluorescence under ultraviolet light, and birefringent crystals and Maltese cross figures under polarized light were again demonstrated. Again there was widespread cholestasis.

\section{Discussion}

The retrospective diagnoses of erythropoietic protoporphyria were made from the photosensitivity from childhood, greatly raised levels of faecal and proto- and coproporphyrins, and from the raised levels of protoporphyrin in the plasma of patient 1, and of protoporphyrin and to a lesser extent coproporphyrin, in red cells of patient 2 . Urine levels of coproporphyrin were usually only slightly above the normal range, but much higher levels were recorded on a few occasions in patient 1. This is unusual in erythropoietic protoporphyria (Rimington, Magnus, Ryan, and Cripps, 1967) uncomplicated by jaundice, but in the patient of Barnes et al (1968) urinary coproporphyrin was greatly increased terminally. This might, therefore, be due to cholestasis. Although erythropoietic protoporphyria is inherited as an autosomal dominant characteristic (Haeger-Aronsen, 1963), the condition was present in only these two of the 11 siblings of the family. The others, however, could not be investigated for latent protoporphria (Lynch and Miedler, 1965).

Blistering of such severity has not been reported before in erythropoietic protoporphyria in which bullae are unusual. Kosenow and Treibs (1953) described a child with blistering of the nose and Langhof, Heilmeyer, Clotten, and Reitschel (1964) blisters in two children. Harber, Fleischer, and Baer (1964) described papulovesicles, while Rimingtonet al (1967) observed some haemorrhagic bullae in one of their cases. Stanoeva, Miovske, and Cadikovski (1971) reported haemorrhagic bullae on the feet alone and finally vesiculo-bullous lesions were noted by Bhutani, Deshpande, and Sood (1972). Both our patients thought that jaundice followed exposure to sun, but a careful history revealed that the intense blistering occurred only after exposure when jaundice had developed. Serum bilirubin, however correlated poorly with the severity of photosensitivity and with the excretion of porphyrins. Protoporphyrin is excreted in bile, its blood concentration being related to the excretory function of the liver (Donaldson et al, 1971; Masuya, Murayama, Hirato, and Nishi, 1964). Faecal and urinary porphyrins are better correlated with the clinical conditions in variegate porphyria (Rimington et al, 1967) and in mice treated with griseofulvin (de Matteis and Rimington, 1963).

The histology of the liver was the same in our patients with cholestasis and intracellular granular protoporphyrin which fluoresced under ultraviolet light, and was similar to that reported by Donaldson et al (1971) and by Barnes et al (1968), who also noted deposition of pigment in lymph nodes. The stability of the fluorescence was surprising, but has been noted before (Roe, Krook, and Wilkie, 1970). Maltese crosses have previously been described in experimental porphyria (Granick and Urata, 1963; Roe et al, 1970). Such an appearance in polarized light is typical of a spherulite containing a radial arrangement of tiny crystals (Bunn, 1964). Around the edges of the rosette, however, the less concentrated porphyrin remains dissolved in lipid, and therefore autofluoresces under ultraviolet light (Granick and Urata, 1963).

The clinical histories of deep cholestasis and cirrhosis were also similar to those reported by Donaldson et al (1971) and Schmidt and Stich (1971) while the patients of Barnes et al (1968) and Scott et al (1971) deteriorated even more rapidly and died a few weeks after presenting with jaundice.

Is the excess protoporphyrin toxic to the liver? Cripps and Scheuer (1965) found early periportal fibrosis in the liver biopsy specimens from patients with erythropoietic protoporphyria but this was 
not related to pigment deposits. Administration of the collidine derivative 1,4-dihydro-2,4,6-trimethyl pyridine-3,5-dicarboxylate (DDC) to rats or pigs (Magnus, Roe, and Bhutani, 1969; Roe et al, 1970) produces protoporphyria, bile duct hyperplasia, a cellular infiltrate in portal tracts, and eventually hepatic cell necrosis. This does not, however, explain why this hepatic lesion is a rare feature of erythropoietic protoporphyria. Protoporphyrin retained within the liver by an initial minor impairment of liver function might cause progressive liver damage. Alternatively, these patients may differ in some way from the majority of those with the condition and if so the occurrence of cirrhosis in these sisters suggests such a difference can be inherited.

Erythropoietic protoporphyria may be associated with four hepatic abnormalities. There are deposits of protoporphyrin in liver cells, canaliculi, and Kupffer cells (Cripps and Scheuer, 1965; Cripps, 1965; Cripps and MacEachern, 1971). Gallstones have been reported in experimental protoporphyria (Cripps, 1965) and in patients with erythropoietic protoporphyria (Magnus et al, 1961; HaegerAronsen, 1963; Scholnick, Marver, and Schmid, 1971), and in at least one patient they contained much protoporphyrin (Cripps and Scheuer, 1965). There is evidence that the production of bilirubin from haem compounds in the liver, and therefore the hepatic synthesis of protoporphyrin, may be abnormally high (Scholinick et al, 1971; Nicholson et al, 1973. Finally there is the uncommon occurrence of cirrhosis and liver failure reported in this paper.

We are very grateful to Drs W. D. Brinton, C. B. S. Fuller, D. A. F. McGill, and E. C. Turton who kindly allowed us to include clinical details of their patients, and to Drs P. Pullar and H. G. H. Richards who provided the postmortem material.

R.P.H.T. was in receipt of a Medical Research Council clinical research fellowship.

\section{References}

Barnes, H. D., Hurworth, E., and Millar, J. H. D. (1968). Erythropoietic porphyrin hepatitis. J. clin. Path., 21, 157-159.

Bhutani, L. K., Deshpande, S. G., and Sood, S. K. (1972). Erythropoietic protoporphyria : First report in an Indian. Brit. med.J., 3, 741-742.
Bunn, C. W. (1964). Crystals: Their Role in Nature and in Science Plate 8. Academic Press, New York and London.

Cripps, D. J. (1965). Iodine tungsten fluorescence microscopy study on erythrocytes in erythropoietic protoporphyria, erythropoietic porphyria of Günther and griseofulvin induced porphyria in mice. Clin. Res., 14, 266.

Cripps, D. J., and MacEachern, W. N. (1971). Hepatic and erythropoietic protoporphyria. Arch. Path., 91, 497-505.

Cripps, D. J., and Scheuer, P. J. (1965). Hepatobiliary changes in erythropoietic protoporphyria. Arch. Path., 80, 500-508.

Donaldson, E. M., McCall, A. J., Magnus, I. A., Simpson, J. R., Caldwell, R. A., and Hargreaves, T. (1971). Erythropoietic protoporphyria: two deaths from hepatic cirrhosis. Brit. J. Derm., 84, 14-24.

England, M. T., Cotton, V., and French, J. M. (1962). Faecal porphyrin excretion in normal subjects and in patients with the 'malabsorption syndrome'. Clin. Sci., 22, 447-457.

Granick, S., and Urata, G. (1963). Increase in activity of delta aminolevulinic acid synthetase in liver mitochondria induced by feeding 3,5-dicarbethoxy-1,4-dihydrocollidine. J. biol. Chem., 238, 821-827.

Haeger-Aronsen, B. (1963). Erythropoietic protoporphyria. Amer. J. Med., 35, 450-454.

Harber, L. C., Fleischer, A. S., and Baer, R. L. (1964). Erythropoietic protoporphyria and photohemolysis. J. Amer. med. Ass., 189, 191-194.

Kosenow, W., and Treibs, A. (1953). Litchtüberempfindlichkeit und porphyrinämie. Z. Kinderheilk., 73, 82-92.

Langhof, H., Heilmeyer, L., Clotten, R., and Rietschel, L. (1964). Die erythropoetische protoporphyrie: protoporphyrinämische Lichdermatose. Dtsch. med. Wschr., 89, 1289-1293.

Lynch, P. J., and Miedler, L. J. (1965). Erythropoietic protoporphyria. Arch. Derm., 92, 351-356.

Magnus, I. A., Jarrett, A., Prankerd, T. A. J., and Rimington, C. (1961). Erythropoietic protoporphyria. Lancet, 2, 448-451.

Magnus, I. A., Roe, D. A., and Bhutani, L. K. (1969). Factors affecting the induction of porphyria in the laboratory rat. Biochemical and photobiological studies using diethyl 1,4-dihydro-2,4,6trimethyl pyridine-3,5-dicarboxylate (DDC) as a porphyrogenic agent. J. invest. Derm., 53, 400-413.

Masuya, T., Murayama, S., Hirato, T., and Nishi, H. (1964). Clinical and experimental studies on porphyrias (A case of erythropoietic protoporphyria). Acta haemat. jap., 27, 349-350.

De Matteis, F., and Rimington, C. (1963). Disturbance of porphyrin metabolism caused by griseofulvin in mice. Brit. J. Derm., 75, 91-104.

Nicholson, D. C., Cowger, M. L., Kalivas, J., Thompson, R. P. H., and Gray, C. H. (1973). Isotopic studies of the erythropoietic and hepatic components of congenital porphyria and 'erythropoietic' protoporphyria. Clin. Sci., 44, 135-150.',

Rimington, C. (1961). Quantitative determination of porphobilinogen and porphyrins in urine and faeces. Association of Clinical Pathologists, Broadsheet, 36.

Rimington, C., Magnus, I. A., Ryan, E. A., and Cripps, D. J. (1967). Porphyria and photosensitivity. Quart. J. Med., 36, 29-57.

Roe, D. A., Krook, L., and Wilkie, B. N. (1970). Hepatic protoporphyria in weanling pigs. J. invest. Derm., 54, 63-64.

Schmidt, D., and Stich, W. (1971). Erythropoetische protoporphyrie mit porphyrinurie. Blut, 22, 202-210.

Scholnick, P., Marver, H. S., and Schmid, R. (1971). Erythropoietic protoporphyria: Evidence for multiple sites of excess protoporphyrin formation. J. clin. Invest., 50, 203-207.

Scott, A. J., Ansford, A. J., Webster, B. H., and Stringer, H. C. W. (1973). Erythropoietic protoporphyria with features of a sideroblastic anemia terminating in liver failure. Amer.J. Med., 54, $251-259$.

Stanoeva, L. J., Miovski, D., and Cadikovski, P. (1971). Erythropoietic protoporphyria. Brit. J. Derm., 85, 540-545. 